\title{
Instagram Social Media As Guidance And Counseling Media Based On Technology
}

\author{
Nur Irma Noviyanti \\ Universitas Negeri Semarang \\ e-mail: noviyanti.nrm@gmail.com
}

\begin{abstract}
: one of the most important counselor tasks to response industrial revolution 4.0 is guidance and counseling service using new innovation, suchus social-media. Internet user Indonesia are $64,8 \%$ from all citizen, with user duration using social-media 3-4 hours each day. Social media acess is the second priority after using communication needed. Instagram is the second social-media with high access by user after facebook. Instagram is one of social-media application to share text, image, or video. This work is gained to analyse that instagram could be used by counselor as media to do guidance and counseling service based on technology. There are many fiture such us image upload, video, caption, comment, hashtags, instagram story, instagram live, direct message and highlight could be used by counselor.
\end{abstract}

\section{Keywords: instagram, guidance and counseling, technology}

Abstrak: Salah satu peran yang dapat konselor lakukan dalam menyikapi dan merespons era revolusi industri 4.0 adalah memberikan layanan bimbingan dan konseling menggunakan inovasi baru sesuai dengan era revolusi industri 4.0 di antaranya menggunakan media sosial. Jumlah pengguna internet di Indonesia mencapai 64,8\% dari total penduduk, dengan lama penggunaan 3-4 jam per hari. Mengakses media sosial menjadi alasan kedua dalam penggunaan internet setelah kebutuhan komunikasi. Hal ini menjadikan instagram berada di peringkat ke-2 media sosial yang paling sering diakses setelah facebook. Instagram merupakan suatu aplikasi yang digunakan untuk membagikan informasi berupa teks, gambar, atau video dengan cepat. Tampilan instagram yang lebih rapi serta fitur yang beragam menjadi daya tarik tersendiri. Tulisan ini menganalisis bahwa media sosial instagram dapat dimanfaatkan oleh konselor sebagai media penunjang program layanan bimbingan dan konseling berbasis teknologi. Melalui fitur-fitur seperti unggah foto atau video, caption, komentar, hashtags, instagram story, instagram live, direct message, dan highlight dapat dimanfaatkan oleh konselor untuk menunjang program layanan bimbingan dan konseling.

\section{Kata Kunci: Instagram, Bimbingan dan Konseling, Teknologi}

\section{INTRODUCTION}

According to a survey of the Indonesian Internet Service Providers Association (APJII), internet users in Indonesia reached 171,17 million $(64.8 \%)$ of the total population of Indonesia in 2018. This is inseparable from the influence of the industrial revolution 4.0 which has brought great changes to human life. The education sector was not immune to the influence arising from this era. Various innovations, creativity, and technological modifications have an impact on the mastery and use of science. Guidance and counseling in the industrial revolution era 4.0 requires the readiness of counselors to expedite and accelerate in providing guidance and counseling services effectively and efficiently (Waris, 2019)

Of all internet users, $93.9 \%$ of users use smartphones to access the internet, with an average duration of 3-4 hours per day. From the results of the APJII survey it is known that accessing social media is the second reason they access the internet in addition to communication purposes. The social media they often access is Instagram, which ranks second after Facebook. Instagram is one of the most popular social media by the community, not only teenagers but also adults. Many teenagers use Instagram for their personal interests,

DOI : https://dx.doi.org/10.26486/ijagc.v1i1.1045

URL : http://ejurnal.mercubuana-yogya.ac.id/index.php/IJAGC/index

Email : ijagc@mercubuana-yogya.ac.id 
such as uploading photos and videos, finding information, watching videos, knowing user activities and much more. By accessing Instagram, viewing photos and videos related to creativity uploaded on Instagram social media can help stimulate creativity in adolescents (Rubiyati, Asrori, \& Wicaksono, 2017).

From these data, counselors must be able to grasp the opportunities for the use of the internet, especially social media Instagram to support the implementation of technologybased guidance and counseling services in the industrial revolution era 4.0.

\section{METHODS}

The research method used in this research is the study of literature, which is an effort made by researchers to obtain information related to the problem being studied. The information was obtained from books, research reports, scientific works, and other written sources. A literature study deals with theoretical studies and other references relating to values, culture, and norms that develop in the social situation under study (Sugiyono, 2012). Besides the study of literature is very important in conducting research, this is because research will not be separated from the scientific literature. Literature studies prioritize literature or references as the main material for linking existing problems in the field with the theories of experts. In conducting a literature study, researchers determine in advance the source of information to be examined. This library research study analyzes the use of Instagram social media in technology-based guidance and counseling.

\section{FINDINGS AND DISCUSSION}

The era of the industrial revolution 4.0 encourages the use of technology in daily activities. In the field of technology education used by teachers and students to access information related to materials that support teaching and learning activities. In relation to counseling guidance, according to (Waris, 2019) there are several roles that counselors can perform in responding to and responding to the era of the industrial revolution 4.0, including:

a. Counselors as one part or component of education in the digital age must work hard and have a strong commitment to developing themselves and learning new knowledge and skills that are in accordance with the needs of today's students and always increasing competence as professional counselors.

b. Able to use and master technology creatively will facilitate the implementation of tasks and can support the implementation of work effectively and efficiently. Such as creating technology-based guidance and counseling programs, as well as making more effective and efficient guidance and counseling service programs as needed.

c. Counselors in providing services using new innovations in accordance with the era of the industrial revolution 4.0, including using social media.

Instagram is an application that allows its users to share photos or videos. Instagram is an iOS, Android and Windows Phone-based application. Instagram is an application for sharing photos that can be seen by followers of the uploader and can comment on one another. The name Instagram comes from the words insta and gram, "insta" which comes from the word instant and "gram" which comes from telegram, can be collected from its name which means to inform or share photos with others quickly (Kertamukti, 2015). Through Instagram users can upload photos and videos, which will automatically appear on the main page of their followers.

Features that can be utilized by counselors to support counseling guidance service programs include:

a. Upload a photo

This feature allows the counselor to upload photos relating to the guidance and counseling service program that will, is being, or has been completed as a venue for 
introducing the guidance and counseling services to the public. The upload can also be in the form of pictures or illustrations containing other important information that is useful for individual self-development.

b. Upload video

This feature can be used by counselors to upload guidance and counseling learning videos that contain motivation or information related to individual development. It can also contain documentation of counseling guidance programs that have been carried out, or as a means of introducing guidance and counseling service programs.

c. Caption

The caption is your writing or information relating to the uploaded photo or video. By writing a caption, it will clarify the contents contained in the upload. An attractive caption will influence the viewer to read the entire contents of the caption. This feature can be used by counselors to provide a textual explanation about counseling guidance program services or important information related to individual self-development that has been illustrated through photos or videos.

d. Comment

This feature serves to provide comments on photos or videos that have been uploaded. Counselors can use it to provide feedback or provide further explanation to users who provide comments on uploaded photos or videos.

e. Hashtags

Hashtags make it easy for counselors to group uploaded photos or videos so that other users can easily find photos or videos according to the desired theme.

f. Instagram story

This feature allows counselors to upload text, photos, and videos. Although uploads in Instagram stories only last for 24 hours, this feature can be used for media promotion when new information is uploaded. In Instagram story there are also other features that counselors can use, such as the question, vote, and so on

g. Instagram live

This feature can be used by counselors to do live broadcasts and discuss certain topics related to guidance and counseling services or other information that is useful for individual self-development, users who see the live broadcast can interact through comments and responded directly by the counselor.

h. Direct message

This feature can be used by users to send messages privately to counselors if there is something to be asked or discussed.

i. Highlight

This feature can be used by counselors to group instagram stories that contain important information related to certain topics making it easier for other users to get that information.

\section{CONCLUSION}

The era of the industrial revolution 4.0 requires the readiness of counselors to expedite and accelerate in providing guidance and counseling services. As technology develops and the increasing number of internet users accessing social media is an opportunity as well as a challenge for counselors to increasingly develop service strategies that utilize social media, especially Instagram. Through features such as uploading photos or videos, captions, comments, hashtags, Instagram stories, live Instagram, direct messages, and highlights can support counseling and guidance service programs

\section{REFERENCES}


Kertamukti, R. (2015). Instagram dan pembentukan citra (Studi kualitatif komunikasi visual dalam pembentukan personal karakter account instagram @ basukibtp). Jurnal Komunikasi Profetik. 08(01), 57-66.

Rubiyati, Asrori, M., \& Wicaksono, L. (2017). Pengaruh pemanfaatan media sosial instagram terhadap kreativitas belajar pada remaja kelas VII. Jurnal Pendidikan dan Pembelajaran Katulistiwa, 7(5), 1-8.

Sugiyono. (2012). Metode penelitian pendidikan. Bandung: Alfabeta.

Waris. (2019). Bimbingan dan Konseling Remaja di Era Revolusi Industri 4.0. Konvensi Nasional XXI Asosiasi Bimbingan Dan Konseling Indonesia. Bandung 27-29 April 2019. 